\title{
The Validity and Reliability of Science Virtual Test on Levels of Organization and Cell Transport Topic (SVT-LOCT) to Assess Students' Science Process Skills
}

\author{
Wafa Hanifah $^{1}$, Nuryani Rustaman ${ }^{2}$, Lilit Rusyati ${ }^{3}$ \\ \{wafarkk@gmail.com ${ }^{1}$ \} \\ International Program on Science Education, Universitas Pendidikan Indonesia, Jl. Dr. Setiabudi 229, \\ Bandung, 40154, Indonesia ${ }^{1,3}$, Department of Biology Education, Universitas Pendidikan Indonesia, J1. \\ Dr. Setiabudi 229, Bandung, 40154, Indonesia ${ }^{2}$
}

\begin{abstract}
The purpose of this study was to analyze the validity and reliability of science virtual test to assess junior high school students' science process skills on levels of organization and cell transport topics, SVT-LOCT. The final design of the instrument was administered to 118 students of 7th graders from two schools in Kabupaten Bandung, Indonesia. The three steps to validate SVY-LOCT are content analysis of levels of organization and cell transport topics, expert judgment and readability test, and trial test (small group try out and larger test). SVT-LOCT was judged through education, content, media, and language by experts and readability test was conducted by teachers and students. The validation resulted in 31 test items that represent eight skills of SPS to assess students' science process skills in levels of organization and cell transport topic. The reliability of SVT-LOCT was considered as high with Cronbach alpha $=0.753$ with correlation of $\mathrm{XY}=0.65$, meaning that the instrument is sufficient to assess students' science process skills.
\end{abstract}

Keywords: Science Virtual Test, Science Process Skills, Levels of Organization, Cell Transport

\section{Introduction}

The development of the advance of technology is resulting the competition in the life aspects. The swift improvement of technology has influenced many areas education, including the testing and assessment area. This competition requires some country change their educational testing system that involves technology in the learning process. The computare simulation assessment as an E-test (electronic testing) is one kind of tools that are always used in teaching process to improve the accuracy and efficiency of taking students' data [1].

The assessment area where testing method has been alternated from the traditional paperbased test to computer-based test is believed to offer need of technology-based assessment in the past year, especially in Indonesia. Since 2013 the national examination in Indonesia has implemented CBA in the form of computer based-test (CBT). However, in utilizing CBT as assessment tools, there are features in CBT that hasn't been utilized well [1]. The CBA has had many advantages, such as decreasing paper use, minimizing cost costs for conducting experiments, providing additional opportunities for testing variants in one trial, and the 
appearance of audio, picture, and video in one test. It is sufficiently advantageous to use computer based test rather than paper based test [2].

Computer-based assessment is believed to be able to discover a new assessment of several process skills in science [3]. In this research, CBT is a virtual test that is being created as the new tool to teach science. It would be interesting and meaningful for learners to implement the science process skill test in the form of a visual test. It is anticipated that students will be able to use technology as their new method of teaching and broaden their understanding, as well as explore their skills in science processing with actual issues served with the exam in images, video and even audio.

The science process skills are described as transferable skills that are applicable to many areas and reflect scientists' habits [4]. They are skills that encourage physical science teaching, ensure efficient participation of learners, allow learners to build a sense of responsibility in their own teaching, enhance lifelong learning, and also provide academic skills to learners [5]. Science process skills as unique competencies that optimize the learning of science, stimulate students, develop students' responsibility of their learning, improve the stability of learning as well as introduce them the techniques of research methods [6]. Learning science process skill is an important method for this purpose.

The term of process skills has been used a lot in the educational discussion as the basis of critical skills needed by students in formulating and evaluating information. Such skills as observing phenomena, comparing information, classifying necessary data, inferring, predicting, and hypothesizing information or news are very much needed by students in learning science [7]. Being said, science process skills are the building blocks of critical thinking skills. Some skills of science process skills are proved to support 21 st-century skills including critical thinking and science literacy.

Science and technology in education is designed to obtain basic skills in science and technology and to critically, creatively and independently cultivate scientific thinking [8]. Experiencing the test of science process skills in a virtual test form, would cover the goal of students to have basic skills in technology as well as have their science process skills assessed in a new way. Being said, this study aims to develop an assessment instrument in the form of virtual test to assess students' science process skills in the specific biology topic, which is levels of organization and cell transport topic.

Noticing that most of the test developed before only covers general science topics, it is important to develop the virtual test in particular subject and topics region. Biology as one of the main life science courses mainly use these skills in the practice, especially in learning about cells and levels of organization. Students need to understand the origin of cells as it is the compulsory topic of biology. As cells are an abstract concept, students need help to virtually draw the image of cells to learn it deeply and meaningfully. Science virtual test would help students in visualizing the content if the topics thus no misunderstood of topics can occur.

\section{Research Method}

The method of this research is development research method which focused on describing the development stages of the instrument and analyzing the validity and reliability of the

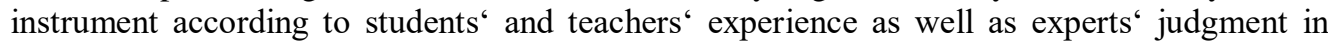
content, education, media, and language [Gravemeijer,1998]. This research method 
corresponds to the study goals of developing a science virtual test on levels of organization and cell transport to evaluate the science process skills of students, since the study relies on the application's growth phases rather than on information collection alone.

The research was conducted by 118 7th graders students of two private schools in Bandung, Indonesia. The schools implemented mixed curriculum of 2013 national curriculum and Cambridge IGCSE curriculum with english as the language used in the learning process and supported by multimedia technology as the learning tool e.g computer, speaker, and headphones for each students. Rubric of experts' judgment and rubric of readability test for teachers and students are used as the instrument to obtain necessary data fro this research.

\section{Results and Discussion}

The result of this research is a set of science virtual test on levels of organization and cell transport topic to assess students' science process skills. The set is compiled of 31 test items which covers eight skills and 24 indicators of science process skills which are interpreting, classifying, applying concept, communicating, predicting, hypothesizing, raising questions, and planning experiment/ investigation. The result was described as the steps of validating the instrument was conducted, which are analysis of content, analysis of experts' judgment in content, education, media, and language, analysis of readability test, and analysis of field test result.

\section{1 Analysis of Levels of Organization and Cell Transport from Curriculum and Science Process Skills Content}

The topics of this research is "Levels of organization and Cell Transport" which is considered as an abstract topic for Junior Highschool students. It is recommended to present the material virtually to avoid misconception among students. The first step to construct the instrument is analyzing the junior high school science curriculum of the science topic. Analysis of science topics has been done to $7^{\text {th }}$ graders science syllabus from two curriculum used in the schools, 2013 National Curriculum and IGCSE Biology Curriculum. The topic is covering six sub-topics from levels of organization and cell transport topics which are cell organelles and function, prokaryotic and eukaryotic cells, plant cell and animal cell, specialized cell, levels of organization, and cell transport as seen in Table 1.

Table 1. Analysis of 2013 National Curriculum and IGCSE Biology Curriculum.

\begin{tabular}{|c|c|c|c|}
\hline Core Competence & Basic Competence & Topic & Sub Topic \\
\hline 3. Memahami dan & 3.6 Mengidentifikasi & Levels of & 1. Levels of organization \\
\hline menerapkan pengetahuan & sistem organisasi & Organization & 2. Cell organelles and \\
\hline (faktual, konseptual, dan & kehidupan mulai & & function \\
\hline prosedural) berdasarkan & dari tingkat sel & & 3. Prokaryotic and \\
\hline rasa ingin tahunya tentang & sampai organisme & & eukaryotic cells \\
\hline ilmu pengetahuan, teknologi, & dan komposisi & & 4. Plant cell and animal cell \\
\hline seni, budaya terkait fenomena & utama penyusun & & 5. Levels of organization \\
\hline dan kejadian tampak mata & sel & & 6. Cell Transport \\
\hline
\end{tabular}


The science process skills used in this research was also analyzed to select the most appropriate skills to be applied in the instrument. Since most of the skills are commonly used in hand-on activities that are not suitable with the implementation of science virtual test the analysis was conducted to choose the appropriate skills. Science process skills in this research was based on Rezba (2003) and Rustaman (2010) which can be seen in Table 2.

Table 2. The science process skills.

\begin{tabular}{|c|c|}
\hline Skills & Indicators \\
\hline \multirow{3}{*}{ Communicating } & Presenting data using figure/table/graph/diagram; \\
\hline & Changing representation of data in different forms; \\
\hline & Reading information/data from table/ figure/ graph/ diagram; \\
\hline \multirow{4}{*}{ Interpreting } & Making inferences from series of observations; \\
\hline & Concluding something from a number of data; \\
\hline & Making sense a number of data; \\
\hline & Finding patterns. \\
\hline \multirow{3}{*}{ Predicting } & Using pattern to explain something \\
\hline & Explaining something that has not happened; \\
\hline & Giving explanation to strengthen something. \\
\hline \multirow{3}{*}{ Raising Questions } & Asking using question marks \\
\hline & Asking questioning words $(5 \mathrm{~W}, 1 \mathrm{H})$ \\
\hline & Asking productive questions \\
\hline \multirow{4}{*}{ Classifying } & Finding similarity \\
\hline & Differentiating; \\
\hline & Looking for criterion/a for grouping; \\
\hline & Placing one object into certain group(s). \\
\hline \multirow{4}{*}{$\begin{array}{l}\text { Planning } \\
\text { Experiment/ } \\
\text { Investigation }\end{array}$} & Identifying variables; \\
\hline & Determining the purpose of experiment/investigation; \\
\hline & Determining equipment/materials; \\
\hline & Making sequence of steps/procedure. \\
\hline \multirow{2}{*}{ Hypothesizing } & Connecting two/more variables in the logic way; \\
\hline & Answering question tentatively. \\
\hline Applying Concept & Using concept in new situation; \\
\hline
\end{tabular}

\section{2 Analysis of Expert Judgment of SVT-LOCT Instrument by Experts of Science Content}

The expert judgment of content of SVT-LOCT was conducted by three experts in science content. This judgment has four aspects assessed in each question, namely (1) figure/ graph/ article/ videos/ audio/ animations used are appropriate with concept and rule of levels of organization and cell transport; (2) the caption/ explanation/ story regarding figure/ table/ graph/ picture/ animation/ articles/ story were appropriate with the concept and rule of levels of organization and cell transport; (3) information regarding "levels of organization and cell 
transport" has been clearly presented/stated; (4) appropriate-ness of biology term application in accordance with the rules of Biology.

Recommendation from experts regarding the content of SVT-LOCT by expert of science content was (1) some questions are still have concept burden; (2) cancer cells article is too complicated to be read by $7^{\text {th }}$ graders; (3) questions number 3 regarding levels of organization is not "interpreting skills" but "applying concept skills"; (4) the video content give direct answer to the question, thus edit the video to certain length and only include important parts on it; (5) There are ambiguous terms in the questions and information; (5) sequence of number on pictures are ambiguous, differentiate it with other numbering to avoid misunderstanding; (6) and (7) Give the axis and title for the graph.

\subsection{Analysis of Expert Judgment of Science Virtual Test on Levels of Organization and Cell Transport (SVT-LOCT) by Experts of Education}

The expert judgment of education of SVT-LOCT was conducted by three experts in science education. This judgment has one aspect assessed in each question, namely (1) questions used are in accordance with sub skills of science process skills. Recommendation from experts regarding science virtual test by expert of education namely (1) state the information (comic and video) clearly; (2) use constant term throughout the test items "cell, tissues, etc"; (3) the word "unless" should be bolded or underlined; and (5) change symbol in table to " $\mathrm{x}$ " to make it easy for students in understanding the question.

\subsection{Analysis of Expert Judgment of Science Virtual Test on Levels of Organization and Cell Transport (SVT-LOCT) by Experts of Media}

The expert judgment of media of SVT-LOCT was conducted by three experts in computer-test media. This judgment has seven aspects assessed in each question, namely (1) composition of text color, text size, and text font; (2) arrangement of each components in SVT-LOCT layout (neatness, easy to read, not to give confusion; (3) appropriate navigation/ icon/ picture usage in the SVT-LOCT (placement, quality, size, color, appropriate function); (4) The position, and navigation bottom were consistent and have the same color and function for each screen; (5) harmony between text, font, and background on the layout; (6) information in the media (video, animation, audio, background sound) have clear intonation, appropriate tempo, clear sound; (7) Background sound/ sound effect attracting but not distracting.

Recommendation from experts regarding the media side of SVT-LOCT by expert of computer test media was (1) fix the subtitle of some videos; (2) fix numbering and arrangement of the questions; (3) soften the color palette of the question layer; (4) change some figure to clearer pictures; (5) there are ambiguous terms in the questions and information; (6) arrangement of icons are not fixed, fix the location of the buttons/icons; and (7) create zoom button for some pictures.

\subsection{Analysis of Expert Judgment of Science Virtual Test on Levels of Organization and Cell Transport (SVT-LOCT) by Experts of Language}

The expert judgment of language of SVT-LOCT was conducted by two experts in English language. This judgment has two aspects assessed in each question, namely (1) Grammar in questions and options are in appropriate use; (2) Using the appropriate English term in the 
questions. Recommendation from experts regarding the language in the questions of SVTLOCT by expert of English language was (1) grammatical error in some questions need to be fixed; (2) use simpler words to be easily understood by students; (3) minor typos need to be fixed.

\subsection{Readability Test of Science Virtual Test on Levels of Organization and Cell Transport (SVT-LOCT)}

Readability test of SVT-LOCT was conducted by three science teachers and three students. Recommendation for this test was (1) (1) instead of using "Erythrocytes", use "RBC (Red blood cell)" because the students are not familiar with the word, (2) additional information needed for "hypotonic, hypertonic, and isotonic, (3) change of symbol " $\mathrm{X}$ " into " $\square$ " to not get the students confused, (4) table or graph should involve enough information, (5) use simpler words, and (6) change the question for cell transport regarding potato into jelly beans.

\subsection{Validity and Reliability of Science Virtual Test on Levels of Organization and Cell Transport (SVT-LOCT)}

The test items that have been validated through experts' judgment and readability test was tried out to 7th grade of students from a public Junior High Schools. The total participants of test were 118 students. The students were taking the virtual test through computer and personal laptop and can directly get the score of the test after finishing all of the questions.

The data obtained from the test were used in the statistical analysis. The analysis of the result was using IBM SPSS Statistics Version 24 and ANATES Program Version 4.1.0. The result show the reliability, item difficulty, item discrimination, and distractor analysis. The item difficulty, item discrimination, and distractor analysis show in which the test items were categorized whether it needs to be rejected, revised, or accepted which can be seen in Table 3 .

Table 3. ANATES 4.1.0 Result (Difficulty index, discrimination power, and distractor analysis).

\begin{tabular}{cccccc}
\hline $\begin{array}{c}\text { No of Test } \\
\text { Item After } \\
\text { Expert }\end{array}$ & \multicolumn{2}{c}{$\begin{array}{c}\text { Discriminating } \\
\text { Power }\end{array}$} & \multicolumn{2}{c}{ Difficulty Level } & Final Decision \\
\cline { 2 - 5 } $\begin{array}{c}\text { Judgment } \\
\mathbf{1}\end{array}$ & $\%$ & $\begin{array}{c}\text { Interpretati } \\
\text { on }\end{array}$ & $(\%)$ & $\begin{array}{c}\text { Interpretati } \\
\text { on }\end{array}$ & \\
$\mathbf{2}$ & 37.50 & Satisfactory & 51.69 & Moderate & Accepted \\
$\mathbf{3}$ & 63.00 & Satisfactory & 75.42 & Easy & Accepted \\
$\mathbf{4}$ & 63.64 & Good & 44.07 & Moderate & Accepted \\
$\mathbf{5}$ & 68.18 & Good & 66.10 & Moderate & Accepted \\
$\mathbf{6}$ & 27.27 & Satisfactory & 61.02 & Difficult & Accepted \\
$\mathbf{7}$ & 63.64 & Good & 69.49 & Moderate & Accepted \\
$\mathbf{8}$ & 31.25 & Satisfactory & 29.66 & Difficult & Accepted \\
$\mathbf{9}$ & 50.00 & Good & 60.17 & Moderate & Accepted \\
\hline No of Test & \multicolumn{2}{c}{ Discriminating } & Difficulty Level & Final Decision \\
\cline { 2 - 4 } & & & &
\end{tabular}




\begin{tabular}{|c|c|c|c|c|c|}
\hline \multirow{2}{*}{$\begin{array}{l}\text { Item After } \\
\text { Expert } \\
\text { Judgment }\end{array}$} & \multicolumn{2}{|c|}{ Power } & \multirow[b]{2}{*}{$(\%)$} & \multirow[b]{2}{*}{$\begin{array}{l}\text { Interpretati } \\
\text { on }\end{array}$} & \multirow[b]{3}{*}{ Accepted } \\
\hline & $(\%)$ & $\begin{array}{l}\text { Interpretati } \\
\text { on }\end{array}$ & & & \\
\hline 10 & 90.91 & Excellent & 29.66 & Difficult & \\
\hline 11 & 12.50 & Poor & 90.68 & Easy & Revised \\
\hline 12 & 78.13 & Good & 47.46 & Moderate & Accepted \\
\hline 13 & 21.88 & Satisfactory & 82.20 & Easy & Revised \\
\hline 14 & 65.63 & Good & 49.15 & Moderate & Accepted \\
\hline 15 & 21.88 & Satisfactory & 40.96 & Moderate & Revised \\
\hline 16 & 46.88 & Good & 55.93 & Moderate & Accepted \\
\hline 17 & 68.75 & Good & 66.10 & Moderate & Accepted \\
\hline 18 & 43.75 & Good & 37.29 & Moderate & Accepted \\
\hline 19 & 68.75 & Good & 44.58 & Moderate & Accepted \\
\hline 20 & 81.18 & Excellent & 28.14 & Difficult & Accepted \\
\hline 21 & 53.35 & Good & 50.00 & Moderate & Accepted \\
\hline 22 & 35.13 & Satisfactory & 44.58 & Moderate & Accepted \\
\hline 23 & 34.68 & Satisfactory & 38.14 & Difficult & Accepted \\
\hline 24 & 46.88 & Good & 56.78 & Moderate & Accepted \\
\hline 25 & 37.50 & Satisfactory & 42.37 & Moderate & Accepted \\
\hline 26 & 18.75 & Poor & 58.47 & Moderate & Revised \\
\hline 27 & 28.13 & Satisfactory & 49.15 & Moderate & Accepted \\
\hline 28 & 53.13 & Good & 59.32 & Moderate & Accepted \\
\hline 29 & 62.50 & Good & 61.86 & Moderate & Accepted \\
\hline 30 & 31.25 & Satisfactory & 25.42 & Difficult & Accepted \\
\hline 31 & 40.63 & Good & 66.95 & Moderate & Accepted \\
\hline
\end{tabular}

There are three categories in which the test items were grouped based on ANATES analysis: accepted, accepted and revision, and rejected. Accepted category has positive correlation with meaning are significance and very significance, accepted and revision has been positive correlation but meaning less than significance, and rejected has been negative correlation. Among 31 test items, 4 items need to be revised while 27 items were accepted. 
Previous version

A student wants to investigate the effect osmosis to plant cell. He recorded how the experiment goes as the video below.

Which hypothesis statement would the student

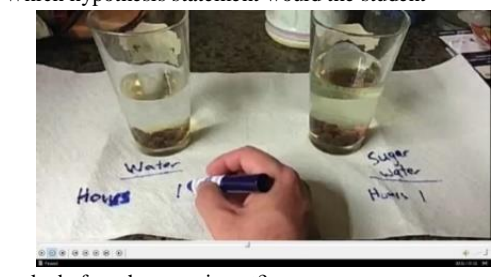

make before the experiment?

A.If raisins are soaked in sugar water, the amoun of water will increase

B.If raisins are soaked in water, the amount of

water will be the same

C.If raisins are soaked in water, the amount of raisins will be doubled

D. If raisins are soaked in sugar water, the size will be smaller

Difficulty Level: Discriminating Power:
Revised version

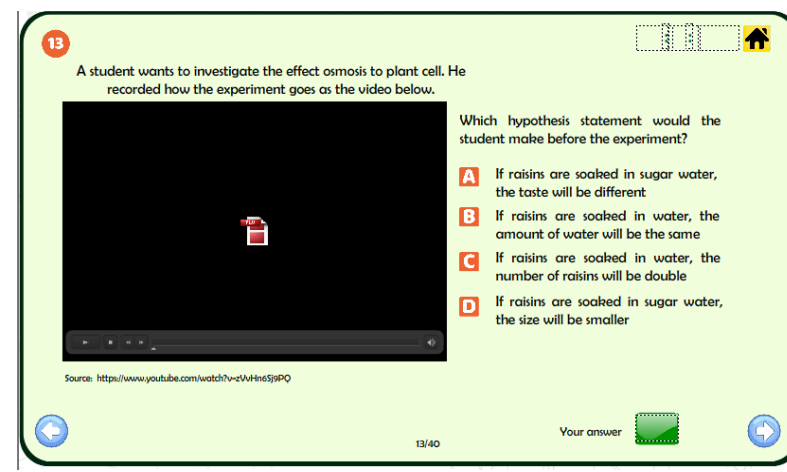

0.82

0.22

Fig 1. Revised Test Item of Number 13.

For example, number 13 was categorized as test item that needs revision. The difficulty level of the test item was 0.82 which was categorized as easy, however the discriminating power of the test item was 0.22 which was categorized as satisfactory. In conclusion the test item needs to be revised to be more reliable and valid.

Table 4. Reliability Result of SVT-LOCT.

\begin{tabular}{ccc}
\hline Number of students & N of Items & Alpha Cronbach's \\
\hline 32 & 31 & 0.718 \\
118 & & 0.753 \\
\hline
\end{tabular}

The steps of conducting field trip were divided into small group try out and larger test with the aim to check the reliability in small number of students and larger number. The result shown in Table 4 . that reliability of 32 students is $\alpha=0.718$ and reliability of 118 students is $\alpha$ $=0.753$. The reliability coefficient $(\alpha)$ of the test is interpreted as 'high' [9] meaning that the test items used in the instrument have high consistency and reliable to measure students' science process skills on levels of organisms and cell transport topic. The result of validity by ANATES 4.1 .0 correlation of $\mathrm{Rxy}=0.63$ which is interpreted as 'high'. Meaning that the test was sufficient enough to assess students' science process skills.

SVT-LOCT contains 31 validated multiple-choice questions that were made constructed based on the skills and indicators of science process skills. The items difficulty index, item discrimination, and distractor analysis have been measured by the ANATES version 4.1.0 analysis. The examples of the test items and its analysis that represents different information of the item (video, article, comic, figure, graph) can be seen in Figure 2. 

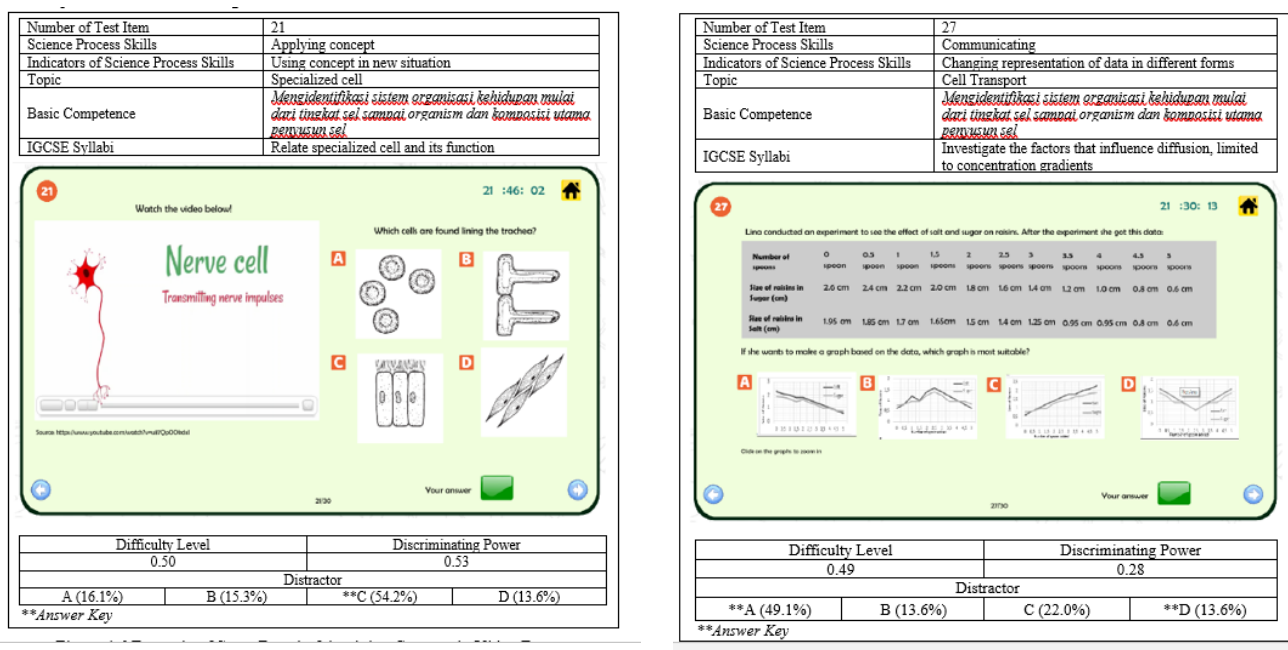

Fig 2. The Examples of Item Card (a) Item Card with Video Information, (b) Item Card with Table and Graph Information.

In Figure 2. (a), the test item number 21 represent applying concept process skill with video and figures as information to answer the question. The question has difficulty level of 0.50 which is categorized as "moderate". The discriminating power of the test item was categorized as "good" discriminating power with 0.53 . The distractor A was chosen by $16.1 \%$ students, distractor B was chosen by $15.3 \%$ students, distractor $\mathrm{C}$ as the answer key was chosen by $54.2 \%$ students, and distractor D was chosen by $13.6 \%$ students which means that the distractors are usable.

In Figure 2. (b), the test item number 27 represent communicating process skill with table as information to answer the question. The question has difficulty level of 0.49 which was categorized as "moderate". The discriminating power of the test item was categorized as "satisfactory" discriminating power with 0.28 . The distractor A as the answer key was chosen by $49.1 \%$ students, distractor B was chosen by $13.6 \%$ students, distractor $\mathrm{C}$ was chosen by $22.0 \%$ students, and distractor D was chosen by $13.6 \%$ students which means that the distractors are usable.

The item analysis includes three statistics to analyze the validity and reliability of the items, the difficulty level of the test items, the discriminating power and the distractors analysis in particular for each of the extensive exam issues. As the example show, the test items are sufficient enough to assess students' science process skills as the reliability and validity was conducted respectively and resulted in high reliability.

\section{Conclusion}

Validation of SVT-LOCT, the instrument to measure students' science process skills on the topic of "Levels of Organization and Cell Transport" in 7th grade Junior High School shows that the developed test are all accepted, but need revision. The reliability of the test is also acceptable. It means the test instrument is sufficient to measure students' science process skills. 


\section{References}

[1] Retnawati, H., Hadi, S., Nugraha, A. C., Sulistyaningsih, E., Djidu, H., Apino, E., \& Iryanti, H. D.: Implementing the computer-based national examination in Indonesian schools: The challenges and strategies. Problems of Education in the 21st Century, Vol. 75, No. 6, pp. 612-633 (2017)

[2] Joshua, A. M., Ikiroma, B., \& Joshua, M. T.: Computer-Based Testing in Nigeria'S University Entrants' Matriculation Examination: Readiness and Acceptability of Critical Stake-Holders. Journal of Chemical Information and Modeling, Vol. 53, pp. 1689-1699 (2013)

[3] Hafizan, Shahali, E. H. M., \& Halim, L.: Development and validation of a test of integrated science process skills. Procedia-Social and Behavioral Sciences, Vol. 9, pp. 142-146 (2010)

[4] Rezba, R. . J., Sprague, C., \& Fiel, R. L. Learning and Assessing Science Process Skills. London: Kendall Hunt, (2003)

[5] Ergül, R., Şımşeklı, Y., Çaliş, S., Özdılek, Z., Göçmençelebı, Ş., \& Şanli, M.: The effects of inquiry-based science teaching on elementary school students'science process skills and science attitudes. Bulgarian Journal of Science \& Education Policy, Vol. 5, No. 1 (2011)

[6] Harlen, W.: Assessment in Education : Principles, Policy \& Practice Purposes and Procedures for Assessing Science Process Skills. Assessment in Education: Principles, Policy \& Practice, Vol. 6, No. 1, pp. 37-41 (1999)

[7] Rustaman, N.: Kemampuan Proses Ilmiah Dalam Pembelajaran Sains. Bandung: Ditjen Dikdasmen Direktorat Pendidikan Dasar, (2010)

[8] Rusyati, L. \& Firman, H. (2017). Validation of science virtual test to assess 8th grade students' critical thinking on living things and environmental sustainability theme. AIP Conference Proceedings, 1848. https://doi.org/10.1063/1.4983984

[9] Jacobs, L. C. \& Chase, C. I. (1992). Developing and Using Tests Effectively. A Guide for Faculty. San Fransisco: Jossey-Bass Inc. 